preference for beef cattle and sheep is due to their greater indirect effect on soil fertility and to the fact that they take far longer to reproduce than pigs and poultry, but much expert opinion is in favour of Dr. Norman Wright's view.

\section{Sir William Chambers}

The July issue of the Anglo-Swedish Review contains an interesting editorial on the life and work of the architect Sir William Chambers, who was born at Gothenburg in 1723, and died in 1796 in London, when he was buried in Westminster Abbey. In 1739 he entered the service of the Swedish East India Company, and the next year sailed to China as a cadet, and in 1743-45 as an assistant. During his stay in China he devoted himself to the study of Chinese architecture, which exercised a considerable influence on his future. The importance of Chambers is due to the fact that he was the first to furnish accurate information on Chinese architectural interior decoration and garden planning based on personal observations in the East. He made his reputation by the grounds which he designed at Kew, including the pagoda in the gardens, between 1757 and 1762. In 1775 he was appointed the architect to Somerset House. He also designed mansions for Earl Gower at Whitehall and Lord Melbourne in Piccadilly. His principal publications were "Designs of Chinese Buildings, Furniture, Dresses, Machines and Utensils" (1757) and "Plans, Elevations, Sections and Perspective Views of the Gardens and Building at Kew in Surrey" (1763).

\section{Biology in Australian Schools}

AT the first public meeting of the Victorian branch of the newly formed Association of Scientific Workers (Australia) held on March 19 in the University of Melbourne, the place of biology in school education was discussed. Prof. J. S. Turner pointed out the inadequacy of the present teaching of science in schools and said that the child is only educated for life if his school science includes an introduction to biology in addition to training in chemistry and physics. The solution of many problems of a troubled world requires biological knowledge-it is enough simply to enumerate them: education, hygiene, nutrition, quack remedies, racial prejudice, population drifts, immigration, agriculture, forestry, soil erosion. Going on to give some statistics regarding Victoria, he showed that inquiries at 36 large schools (including 4 of the largest public schools) revealed that 17 of these schools do not teach biology at any stage to their 6,300 pupils. At the other 19 schools there are 8,000 pupils, 2,500 of whom were of Intermediate or Leaving standing. Of these, 254 take biological science, 230 botany, 570 zoology. In Victoria there are 150 State Secondary, High and non-State Secondary schools, and in only 77 of these is any kind of biology taught. Of the 77 schools teaching biology only 5 or 6 are boys' schools or mixed schools, and it appears probable that in any one year only a hundred or two hundred boys in the whole of the State are introduced in a scientific study of animals, plants and man. Of the 3,500 boys and girls who in 1938 took English and arithmetic in public examinations, 2,050 took also British history ; 400 (all girls) took botany, 500 (about 100 boys) took zoology and 72 took agricultural science.

Prof. S. M. Wadham discussed the lack of biological training in citizens in connexion with the various political systems; he pointed out that the successful introduction of biology in English schools during the last decade was in part due to the decision to allow medical students to pass their first M.B. examination while still at school. Biology is largely a cultural subject, and its introduction into schools would be opposed unless it could be shown to be of direct advantage in later life. Mr. Colman, Inspector of Schools in Victoria, agreed that an extension of biological teaching was desirable, but discussed the difficulties of school time-tables. He showed that attempts were being made to introduce courses of biological and physical sciences into the State schools. Miss Cunningham, of Fintona School, gave her opinion that time-table difficulties are by no means insuperable, and thinks that there can be no argument as to the cultural value of biology in schools. She has introduced a compulsory course dealing largely with human physiology and she found her pupils vitally interested. Prof. R. D. Wright said that the average person's abysmal ignorance of dietetics and normal functions is to be deplored. $\mathrm{He}$ is inclined to the view that biology, dealing with variable material, is of greater value as a school science than pure physics or chemistry.

\section{Conserving Supplies of Potash Alkalis}

WITH the object of ensuring that the reduced supplies of potash compounds shall be used to the best advantage the Ministry of Supply has made an Order under which purchases by consumers of caustic potash and carbonate of potash may be made only under licence. Licences will not be granted except in cases where substitution of potash by soda is impossible, but for the present, lots not exceeding half a ton a month are exempt from the Order. Compared with the vast quantities of potassium compounds used as fertilizers the amount used in the manufacture of medicinal salts is small; at a rough estimate it is probable that it does not exceed 5 per cent of the total consumption of potash; but it is desirable, nevertheless, that medical practitioners should prescribe sodium or ammonium compounds instead of potassium compounds whenever this substitution can be made without prejudice to patients. For example, sodium or ammonium bromide should be used instead of potassium bromide and sodium iodide in place of potassium iodide; and so the list might be extended. In the aggregate, the quantity of potash saved for potatoes and other market garden crops and sugar beet, for example, would not be inconsiderable.

\section{Infectious Diseases and Aeroplanes}

IN a recent thesis (Thèse de Paris, No. 217 ; (1940), Dr. J. M. Chauvise remarks that in addition to the precautions applicable to passengers on aeroplanes 
coming from countries in which malaria, yellow fever and dengue are present, special prophylactic measures are necessary for destruction on the aeroplanes of the insects carrying these diseases. This prophylaxis should be carried out both on departure by a rigorous supervision of the openings in the machines and on arrival by a careful examination of the machine and a search for the hiding places of dangerous insects. The method at present employed consists in the use of a spray with various kinds of pyrethrum, though flies, ticks, bugs and other sorts of insects are not destroyed by it. Disinfestation of the machine during flight should be carried out by an apparatus containing a mixture of pyrethrum and carbon tetrachloride possessing the following characters : (I) it should be rigorously non-inflammable ; (2) it should have no injurious action on metals or materials ; and (3) it should not irritate the passengers' mucous membranes. Inspection of the aerodrome should include a search on the aeroplanes for the internal and external hiding places of mosquitoes into which ordinary disinfestants cannot enter without direct spraying. There is a general tendency to neglect entirely the outside of the aeroplanes, although it contains numerous possible places of concealment for mosquitoes.

\section{Food of Fur Animals in Captivity}

Prachically the only animals that are now being bred commercially for their fur are silver-foxes, minks and rabbits. Others have been tried, but costs of feeding, overhead charges generally, and difficulties of inducing breeding in captivity made the price of the skins greater than that of equally good wild-caught examples, so that the undertakings came to an end. To some extent, the first needs in this relatively new industry were the testing of equipment, the perfection of methods of management, and the eontrot of diseases and parasitic infestations. These problems have been tackled, but until recently no attempt had been made to discover by controlled experimental work the diets most suitable as regards results and costs for the carnivorous animals recently taken from the wild. The Yearbook of Agriculture for 1939 of the U.S. Department of Agriculture contained an article by Charles E. Kellogg on "Nutrition of Fur Animals", which has been reprinted as Yearbook Separate No. 1717 (U.S. Govt. Printing Office, 1940). It contains in 22 pages a summary of the scientific work carried out at the four or five experimental stations in the United States where nutritional research with fur animals has been carried out. It is impossible to indicate the findings here; but they should be of value to breeders of fur animals in this country, whenever circumstances permit again the development of the fur-farming industry.

\section{A Flooded Power Station}

ON August 20, 1939, a flood occurred at Tientsin in China which is stated to have been of unprecedented dimensions even for that part of the Far East, where floods are not infrequent. Mr. F. A. Matthews, chief engineer of the Electricity Department, British
Municipal Council, Tientsin, tells a graphic story of this terrible flood, according to the Electrical Times of August 8. Despite elaborate precautions, within a few hours the water forced its way into the station basements of the hydro-electric plant until the depth of the water was $6 \mathrm{ft} .6 \mathrm{in}$., and the power station was crippled for five weeks. The dyking of the power station compound and entrance was commenced immediately and in about four weeks it was possible to hold the flood waters at a safe level by pumps. Reconditioning of the flooded auxiliaries followed, and on September 24 the department was able to take over the load of the area from the Belgian Tramways Co., which had been giving a temporary supply.

The two large Metro-Vick turbo sets, each of 2,500 kw. capacity, had perforce to stop during the floods, and the opportunity was taken to recondition them. Alterations and improvements were also made in the boiler plant, giving marked betterment in coal consumption and heat recovery. Earlier in the year, restrictions and blockade had had an adverse effect on load conditions generally and many factories had to shut down. Members of the Electricity Department staff living outside the concession found it extremely difficult to get to and from their homes, and they had therefore to be housed within the Concession's boundary. In the latter part of the year, load conditions improved, and records were made by both income and profits.

\section{July Earthquakes}

THe U.S. Coast and Geodetic Survey in co-operation with Science Service and the Jesuit Seismological Association has made a preliminary determination of the epicentres of five earthquakes which occurred during the early part of July 1940. The first on July 6 had an epicentre in the sea to the north of Toco in Trinidad, and a fairly deep focus, probably of the order of $175 \mathrm{~km}$. The second on July 10 took place to the north-east of Kirin in Manchukuo. This may have been a very deep focus earthquake with a depth of focus in the neighbourhood of 450 $\mathrm{km}$. The third on July 13 was in the Pacific Ocean to the south of P. Burica in Central America. The fourth on July 14 had an epicentre near Rat Island in the Aleutian Islands group, and the fifth on July 19 had its epicentre in the sea bed to the north of Attu also in the Aleutian Islands group. The above determinations, based on reports from twenty-two seismographic stations, indicate the continuation of recent activity in the Aleutian Islands, and off the Pacific coast of Central America. The shock near Trinidad is a continuation of previous activity and the deep focus earthquake near Kirin extends to the north-west the previously known Japanese deep-focus portion of the circum-Pacific belt.

\section{Indian Statistical Conference}

THE second session of this Conference was held in Lahore in January 1939 ; the Proceedings were published in March 1940 and were received here in August (Edited by P. C. Mahalanobis. Pp. ii +168 . Calcutta : 